Анатолій Дерев'янчук, кандидат технічних наук, професор Сумський державний університет ORCID ID 0000-0001-6881-560X

\title{
ПІДХІД ДО СТВОРЕННЯ І ЗАСТОСУВАННЯ КЕЙС-МЕТОДУ ПРИ ВИВЧЕННІ ВІЙСЬКОВО-ТЕХНІЧНИХ ДИСЦИПЛІН
}

\begin{abstract}
Висвітлюеться сутність застосування методу «Case-study», як інтерактивної форми навчання студентів військово-технічним дисциплінам з метою підвищення рівня якості викладання дисиипліни «Будова та експлуатація артилерійського озброєння».

Надаються етапи створення кейсів, їх зміст та методика проведення занять.

Ключові слова: інтерактивні методики; кейс-метод; технології навчання.
\end{abstract}

Постановка проблеми. Актуальність дослідження процесу та динаміки підготовки офіцерів запасу, що проходять навчання на кафедрі військової підготовки університетів визначається, в першу чергу, військовим конфліктом на сході України, що триває упродовж чотирьох років. Останній спонукав відобразити, дати характеристику і зробити оцінку поточному стану проблем, які існують у ЗСУ. Найбільш складною і актуальною виявилась проблема недостатнього рівня підготовки фахівців різних категорій, у тому числі серед фахівців РВ і А. Недостатність необхідного практичного досвіду, відсутність бойових стрільб, знань, умінь експлуатувати штатні зразки озброєння призвели до великих матеріальнотехнічних втрат і людських ресурсів. Відсутність досвідчених фахівців в ремонтних органах $\mathrm{PB}$ i А затримували своєчасний i якісний ремонт озброєння і військової техніки (ОВТ).

У контексті викладеного, заходи щодо підвищення якості навчання 3 точки зору удосконалення практичних навичків, вміння швидко і правильно оцінювати обстановку i приймати правильні рішення потребують інноваційних підходів до системи підготовки та зміни поглядів фахівців.

Як показує досвід, знання та практичні навички, отримані студентами упродовж навчання, з часом зменшуються, втрачають свою цінність. Після мобілізації такі військові потребують певного часу для відновлення знань i вмінь. Таке пояснюється тим, що при навчанні вони не отримали досвіду самостійно опрацювати проблему, що виникла, знайти причину і прийняти правильне рішення на ії усунення. Крім того, молоді командири не завжди уміють спілкуватися з підлеглими, які вже мають певний досвід, радитися 3 ними і спільно шукати можливі вирішення проблеми.

Однак відслідковується недостатня орієнтація ВЗВО на формування у слухачів якостей, що наведені вище. Це позначається на якості підготовки спеціалістів.

Кафедрою військової підготовки Сумського Державного університету розробляється i починає впроваджуватися новітній проект інтеграції інформаційних технологій і кейс-методів у навчально-виховний процес. Таке 
диктується актуальною необхідністю підвищення якості навчання завдяки розвитку здібностей слухачів до сприйняття, ефективного осмислення (переопрацювання) і засвоєння інформації, засвоєння технології до пошуку нестандартних рішень.

Зазначимо, що кейс-метод широко застосовується у економіці, юриспруденції, у середніх навчальних закладах, психології, медицині, бізнеснауках тощо. Однак у навчально-виховному процесі ВЗВО і на кафедрах військової підготовки він ще не отримав поширення.

Метою статті є осмислення розробки і застосування кейс-методів у системі підготовки військових фахівців РВ і А.

Отже, із викладеного вище, актуальність даної роботи обумовлена протиріччям між підвищеною потребою i об'єктивною необхідністю формування у майбутніх фахівців аналітичних i практичних умінь, i недостатньою розробкою засобів $\mathrm{i}$, власне, кейс-технологій для отримання поставленої мети.

Досягнення цієї мети передбачає вирішення наступних питань:

• осмислити сутність і структуру кейсу;

- сформувати вимоги до кейсу;

• розробити основні методичні прийоми проведення кейсу;

•надати рекомендації щодо впровадження кейсу в практику навчання.

Методи дослідження: аналіз, узагальнення літературних джерел i досвіду підготовки фахівців, результати експериментальних досліджень.

Аналіз останніх досліджень і публікацій. В останні роки по «кейсстаді» з'явилось дуже багато матеріалів в Internet, в літературі 3 менеджменту, педагогіці тощо.

Так, вагомий внесок у розвиток застосування кейсів присвячені роботи $[2,3,7,8]$. У них обгрунтована необхідність використання кейс-методу для підвищення якості навчання у ЗВО.

Роботи [1,4,5,6] присвячені побудові кейс-методу, етапам його створення і рішення поставлених проблем, а також розглядаються етапи дослідницьких, комунікативних і творчих навичок майбутніх спеціалістів.

У даній статті ми зупинимося на огляді застосування «кейс-стаді» у закладах вищої освіти, методика застосування яких найбільш придатна до інтеграції у підготовку військових фахівців як у ВЗВО, так і на кафедрах військової підготовки.

Виклад основного матеріалу.Розглянемо сутність застосування кейсметоду більш ретельно, так як він ще не знайшов широкого впровадження у навчальний процес В3ВО і кафедр військової підготовки.

Кейс-метод (case-study) - це технологія навчання, що використовує реальні військово-технічні, військово-тактичні, психологічні, військовомедичні і інші ситуації (від англ. case - «випадок»).

Сутність кейс-методу полягає в тому, що засвоєння знань і формування вмінь $\epsilon$ результатом активної самостійної діяльності студентів (курсантів) 3 вирішення потреб, які виникають у повсякденній діяльності військових 
підрозділів і, в силу цього, відбувається творче опанування професійними знаннями, навичками, вміннями i, що важливо, розвиває здібності мислити.

Що ж таке кейс? Кейс являє собою опис конкретної реальної ситуації (у подальшому буде розглядатись військово-технічна ситуація) підготовлену за спеціальним форматом і призначену для навчання студентів (курсантів) аналізу різних видів інформації, ії узагальненню, пошуку можливих варіантів іiї вирішення.

При цьому важливо знати, що методи передачі знань визначаються як педагогічними технологіями, так і інформаційними можливостями студента (курсанта) i, зокрема, кафедри.

Основною метою навчання з військово-технічних дисциплін кафедри, $€$ формування знань i компетенцій, необхідних для молодого офіцераартилериста, які потрібні в особливий період 3 обмеженим лімітом часу $\mathrm{i}$ озброєнням.

Для читача, який вперше зустрічається 3 кейс-методом, запропонована модель процесу навчання, яка в зрозумілій формі дає уяву про сутність методу (рис.1).

Звичайно, використання кейс-технологій у навчанні не вирішують всіх проблем сьогодення. На наш погляд, найбільшого ефекту можна досягти при розумному поєднанні як традиційних, так i інформаційних технологій навчання (використання 3D моделювання, анімаційних відеороликів, віртуальних тренажерів, тестів, тощо), коли вони доповнюють один одного.

Але відмінною особливістю методу кейсу $\epsilon$ створення проблемної ситуації на основі фактів 3 реальної військової обстановки (марш артилерійських підрозділів, бойові стрільби, ремонт ОВТ, тощо).

Для того, щоб навчальний процес на основі кейс-технологій був ефективним необхідно створити (побудувати) хороший i цікавий кейс i застосувати відповідну методику навчання.
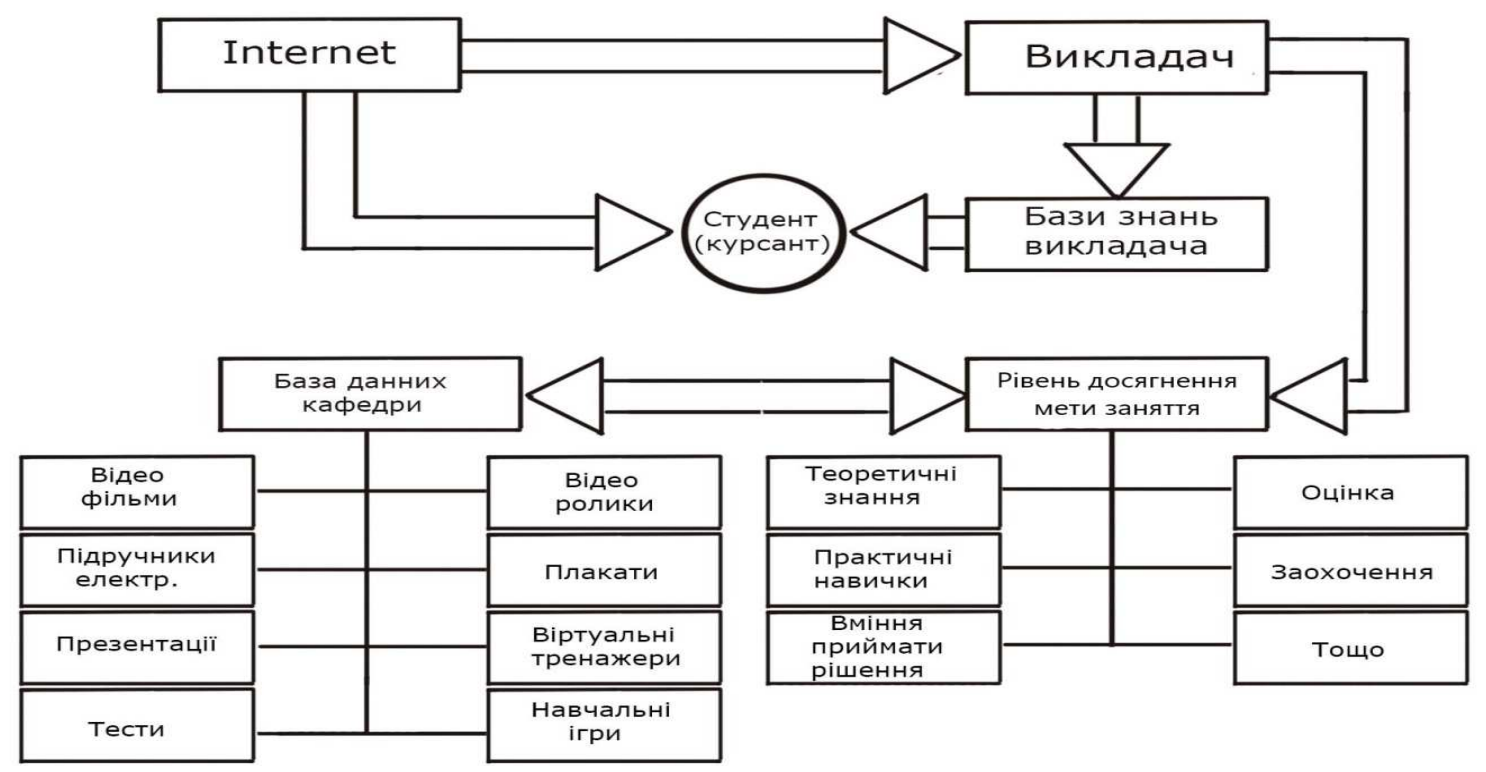

Рисунок 1- Спрощена модель процесу навчання кейс-методом 
Відповідно до сказаного вище, кейс-метод повинен моделювати життєво-професіональну ситуацію (необхідно враховувати, і психологічний аспект) діяльності військовослужбовця, сприяти розвитку аналітичних, комунікативних навиків, що дозволяв би визначати проблему, з якою прийдеться офіцерам зіткнутися у майбутній професіональній діяльності.

Систематичне застосування кейс-методу допомагає слухачам миттєво і правильно оцінювати обстановку і приймати рішення, крім того, вони відчувають своє «Я» - я знаю, я вмію, я можу.

На жаль, рамки статті не дозволяють повністю розширити всі методичні аспекти використання кейс-технологій. Тому зупинимося на основних проблемах, які в певній мірі розкривають читачу сутність метода кейс i методику його застосування.

Зауважимо, що на відміну від традиційних методів навчання, кейстехнологія орієнтована на «научення», а не на вивчення чого-небудь, тобто вона призначена для розвитку у студентів уміння самостійно приймати рішення і знаходити правильні відповіді на питання

Почнемо 3 того, що студентам пропонують осмислити реальну військово-технічну ситуацію, опис якої відображає не тільки яку-небудь практичну проблему, але й актуалізує певний комплекс знань, який необхідно засвоїти при вирішенні даної проблеми. При цьому сама проблема не має однозначних рішень.

Відмітимо, що величина кейса залежить від його призначення. Так, наприклад, для студентів першого року навчання доцільно застосовувати міні-кейс, який займає за обсягом від однієї до кількох сторінок (за часом як частину двогодинного заняття).

Для студентів другого курсу навчання можна застосовувати кейс середніх розмірів (займає двогодинне заняття).

Розглянемо послідовність побудови кейса, або, як прийнято, етапи побудови, від правильності їх змісту буде залежати успіх застосування кейсу.

В першу чергу необхідно сформувати дидактичну мету кейсу. Потім визначити проблемну ситуацію (визначити конкретний випадок).

3 викладеного вище, будемо розуміти наступне: якісний кейс розповідає i фокусується на темі; не виходить за межі програми, кейс містить відеоролики, фрагменти відеофільмів, таблиці, діаграми, графіки тощо, а також проблеми зрозумілі курсантам.

Як показує досвід, якщо тема об'ємна , то доцільно розробляти декілька кейсів і надавати можливість студентам самостійно вибирати кейс (рис. 2). 
Кейс №1

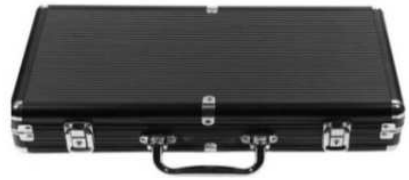

a
Кейс №2

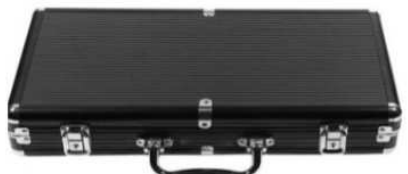

6

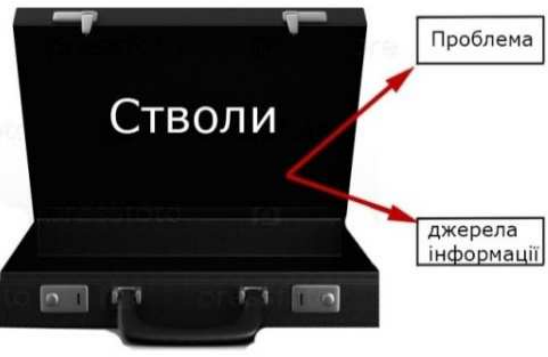

B

Рисунок 2 - Набір кейсів: а,б - закриті кейси; в - вибраний кейс

На інтерактивній дошці виставляються три кейси (рис. 2). При наведенні курсору миші на конкретний кейс-він відкривається і появляється тематика кейсу (рис 2, в). В інших кейсах може бути тематика з боєприпасів, будови гармат, бойового застосування тощо.

Через декілька секунд із кейсу «випливає» проблема (конкретна ситуація), яку студенти повинні вирішити.

Після ознайомлення із задачею, із кейсу «випливає» перелік джерел інформації згідно теми проблеми (ситуації) (рис .2 в).

Завдання творчого характеру може бути таким.

Ви - командир взводу самохідних гаубиць 2С1 (2С3M).

У вашому розпорядженні $є$ : Таблиці стрільби гармати, штатні боєприпаси, екіпаж знаходиться на своїх робочих місцях і готовий виконувати свої функціональні обов'язки.

3 командного пункту доповіли, що при стрільбі другої гармати снаряди постійно не долітають до цілі.

Отже ми сформулювали одну конкретну проблему, яка i $€$ першим кроком нашого кейсу.

Студенти самостійно ознайомлюються зі змістом кейсу.

Другий крок кейса - це проведення опитування 3 точки зору розуміння змісту кейсу без детального обговорення.

Третій крок. Викладач розподіляє студентів на мікрогрупи (4-6 чоловік).

Четвертий крок. Організація обговорення змісту кейсу в мікрогрупах. Як правило, в мікрогрупах визначають лідера, найбільш підготовленого студента.

П'ятий крок. Кожна мікрогрупа створює свої пропозиції відносно вирішення проблеми.

Шостий крок. Презентація рішень.

Сьомий кро. Обговорення рішень і результатів разом з викладачем.

Після закінчення обговорення рішень і результатів, викладачу необхідно оцінити знання студентів.

Звичайно, кожен викладач у залежності від досвіду, широти кругозору, загальної ерудиції може використовувати свої критерії оцінювання.

На наш погляд, основними критеріями оцінювання можуть бути: 
•професійне і практичне вирішення проблеми;

•новизна і неоднорідність вирішення проблеми;

•якість оформлення матеріалів і чіткість викладення рішення проблеми;

• вміння ведення дискусії, етика поведінки.

При постійному застосуванні кейсів, викладач зможе виявляти наскільки отримані студентами, а саме: аналітичні-вміння аналізувати данні; виділяти основну інформацію; практичні - використання теорії на практиці; творчі - розвиток нестандартного мислення і підходів вирішення проблеми.

3 метою удосконалення створення кейсів та методики їх застосування серед студентів на предмет оцінки кейсу можуть бути поставлені такі питання:

- Чи сприяє кейс кращому засвоєнню матеріалу?

-Чи мотивує кейс до поглибленого вивчення як навчального матеріалу, так і додаткової інформації?

-Як Ви пов'язуєте отримані знання з майбутньою професіональною діяльністю?

- Чи почуваєте себе більш впевненим при захисті своєї точки зору та проблеми?

- Чи допоміг вам кейс абстрактно мислити і вірно приймати рішення?

Результати опитування відображені на рис.7. Приблизно $18 \%$ студентів не оцінили кейс-метод за причини нерозуміння окремих його положень (на рисунку не показано).

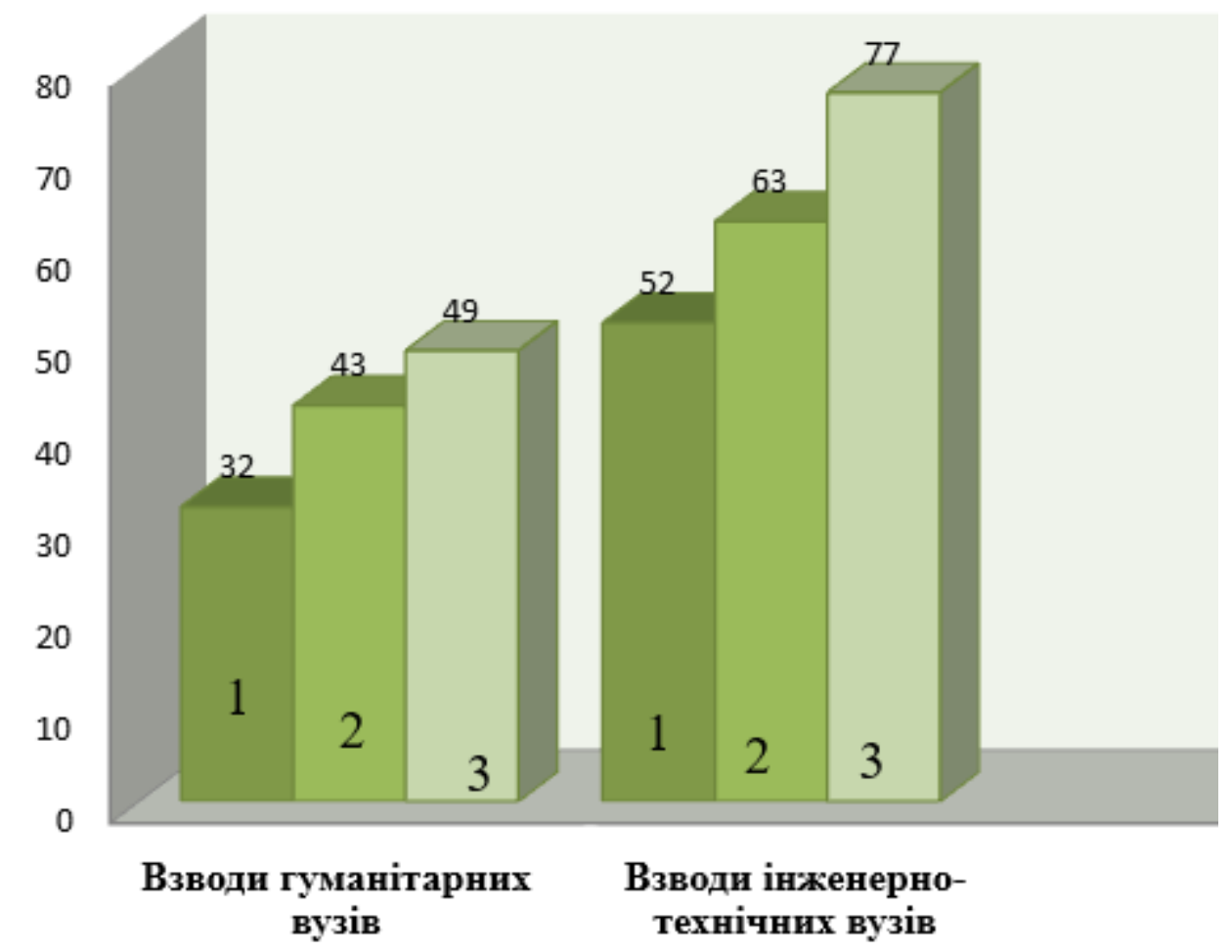

Рисунок 4 - Рівень оцінювання кейс-методом студентами:

$1,2,3$ - умовні позначення навчальних взводів. 
Як приклад, наведемо дії однієї із підгруп взводу інженерно-технічного вузу при рішенні названого вище кейсу.

Зазначимо, що курсанти можуть користуватися базою даних кафедри (рис.1) та Internet, де відбирається необхідна інформація.

Потім відпрацьовуються (розроблюються) варіанти індивідуальних рішень, проводиться обговорення індивідуальних рішень у підгрупі (вибір найкращого).

На екрані монітора виводиться інформація (відеоролики, фотографії, плакати, тощо) використовуючи яку, студенти створюють різні варіанти рішення проблеми.

Так, при постановці питання кейсу підгрупа відбирає ту інформацію (факти), що впливають на вирішення мети. У нашому випадку це може бути неправильне встановлення установок прицілу, незадовільна робота навідника, неправильне комплектування зарядів, неправильний вибір снарядів (помилки заряджаючого), проблеми 3 досилачем, вплив стану каналу ствола гармати, у формуляр не внесена поправка $\left(\Delta \mathrm{V}_{0}\right)$ на зміну початкової швидкості снаряду тощо. Це - неповний перелік питань над якими працює підгрупа.

Після аналізу джерел інформації, наведених вище проблем, студенти приходять до загального висновку шляхом дискусії і готують презентацію.

Послідовність презентації може бути наступною.

Представлення 3D моделі ствола гармати 2C3M (рис.5), 3 поясненням його характеристик, що впливають на дальність стрільби (додатково надається 3D модель бойового відділення гармати (рис.6), де пояснюються окремі чинники, що впливають на дальність стрільби.

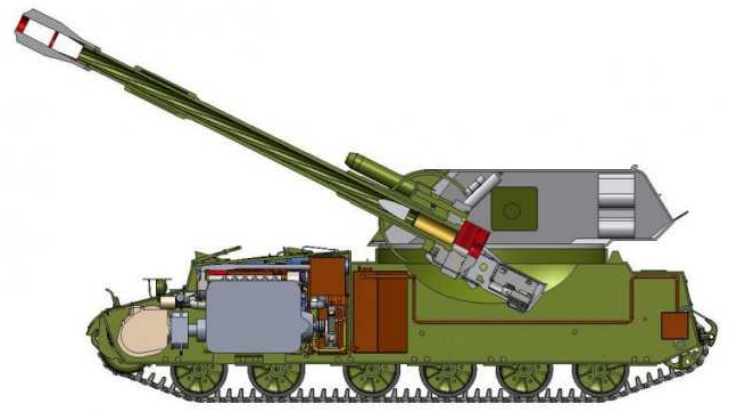

Рисунок 5 - Загальний вигляд гармати $2 \mathrm{C} 3 \mathrm{M}$

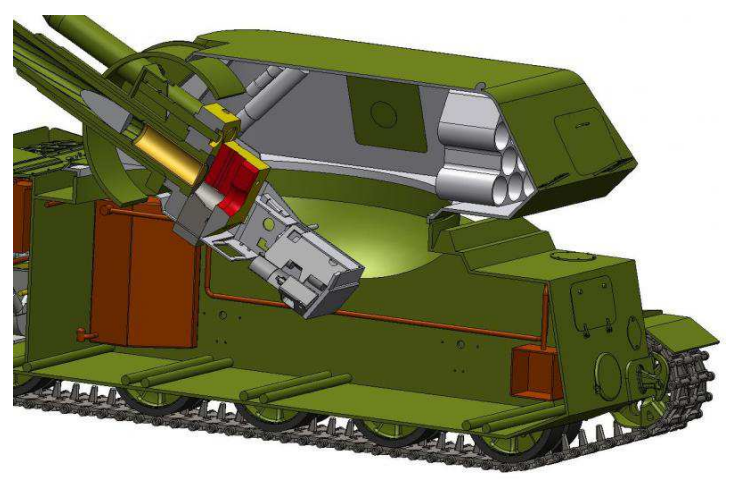

Рисунок 6 - Бойове відділення гармати $2 \mathrm{C} 3 \mathrm{M}$

У підсумку підгрупа визначила, що на дальність стрільби впливає знос нарізної частини каналу ствола (подовження зарядної камори).

Для виміру подовження камори вони рекомендують застосувати прилад заміру довжини камори лазерний( ПЗК-Л), розроблений кафедрою (рис.7). 


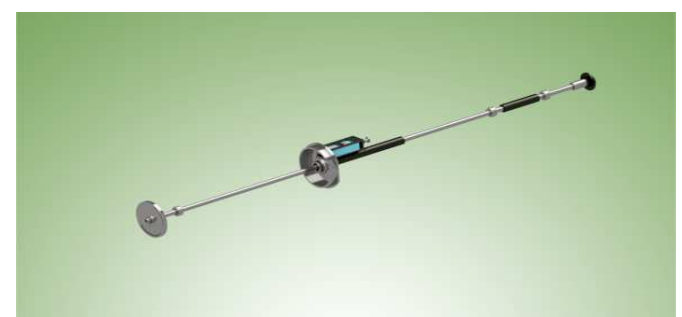

a

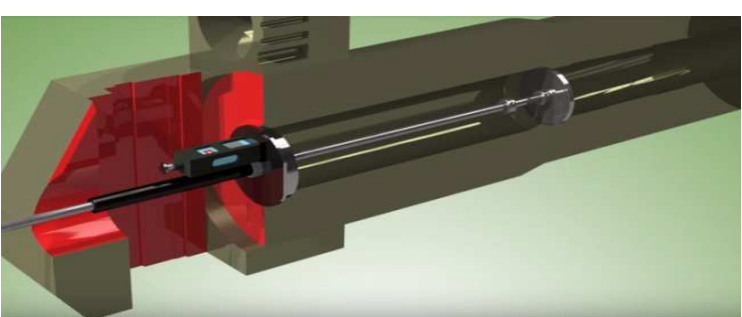

6

Рисунок 7 - Прилад ПЗК-Л:

a - ПЗК-Л у зібраному стані; б - ПЗК-Л у каморі ствола

Із викладеного вище, $\epsilon$ можливість навести спрощену блок-схему методики проведення заняття із застосування кейс-методу (рис.8).

Нагадаємо, що роль викладача не пасивна, як стороннього спостерігача. В процесі заняття він може надавати ключі до розгадування у вигляді додаткових кроків або додаткової інформації, а в деяких випадках і сам дає відповіді на окремі питання.

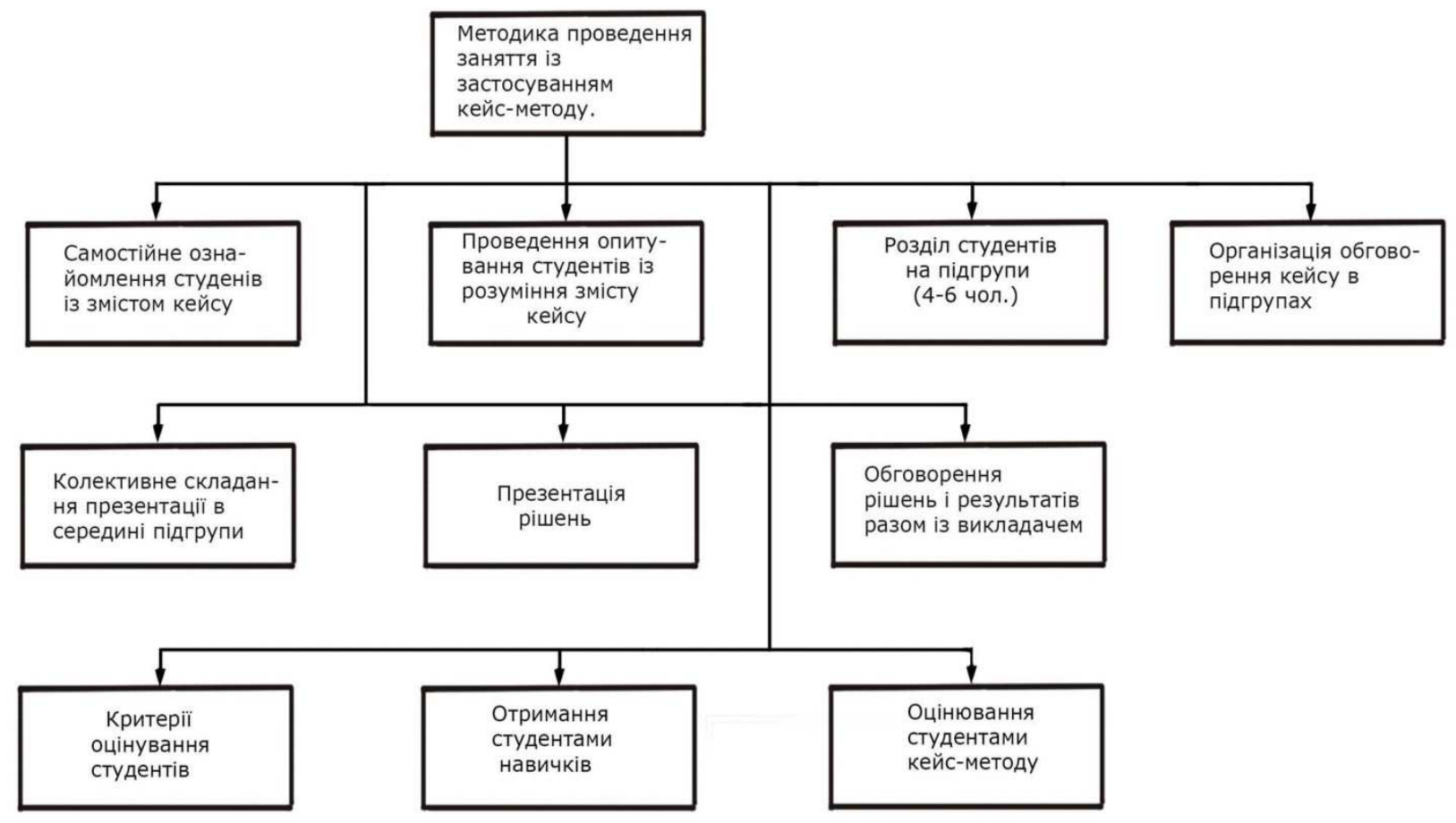

Рисунок 8 - Спрощена блок - схема методики проведення заняття із застосуванням кейс - методу

Висновки і перспективи подальших досліджень. Метод кейсів, за умови поєднання традиційних i інтерактивних методів, надає змогу студентам (курсантам) підвищити рівень як теоретичних знань, так i практичних вмінь і навичок у сфері аналізу конкретних ситуацій.

Кейс-метод змушує студентів самостійно шукати інформацію, мислити, виділяти головне у конкретній ситуації i знайти правильне вирішення проблеми, посилює мотивацію до своєї майбутньої військовопрофесіональної діяльності. 
На наш погляд, доцільно проводити дослідження у таких напрямках:

•удосконалення структури кейс-методу;

• виявляти та усувати недоліки і запроваджувати позитивні сторони кейсів;

•удосконалювати методику проведення кейсів;

•продовжувати розробку методичних рекомендацій при роботі з кейсом.

\section{ЛIТЕРАТУРА}

1. Верба В. Методичне наповнення курсу «Проектний аналіз» / В. Верба // Ситуаційна методика навчання: український досвід: збірник статей; упор. О. Сидоренко, В. Чуба. - К.: Центр інновацій та розвитку, 2001. - С. 165-170.

2. Долгоруков А. Метод case-study как современная технология профессиональноориентированного обучения [Электронный ресурс] / А. Долгоруков. - Режим доступа : http://www.vshu.ru/ lections.php?tab_id=3\&a=info\&id=260

3. Жигилей И. М. Формирование профессиональных компетенций с помощью кейсметода в высшем образовании / И.М. Жигилей // Преподаватель XXI век. - 2012. - № 1. C. 29-36.

4. Малышева М.А. Современные технологии обучения и их роль в образовательном процессе [Текст] / М.А. Малышева // Современнные технологии обучения в вузе (опыт НИУ ВШЭ в Санкт-Петербурге). - СПб., 2011. - С. 6-25.
5. Основы кейс-метода
[Электронный
pecypc] http://www.pprog.ru/Osnovi\%20keis-metoda.doc

6. Погребельная Н. И. Кейс-метод как условие формирования исследовательских способностей студентов вуза / Н. И. Погребельная // Наука и школа. - 2008. - № 1. - С. 73

7. Сурмін Ю. П. Метод аналізу ситуацій (Case-study) та його навчальні можливості. Глобалізація і Болонський процес: проблеми і технології: Кол. моногр. - К.: МАУП, 2005.C. $71-82$

8. Ситуационный анализ, или Анатомия Кейс-метода / Под ред. д-ра социологических наук, профессора Сурмина Ю.П. - К.: Центр инноваций и развития, 2002. - C. 41-56.

\section{REFERENCES}

1. Verba, V., Sydorenko O. (2001). Metodychne napovnennia kursu «Proektnyi analiz» [Methodical content of the course "Project Analysis"]. Sytuatsiina metodyka navchannia: ukrainskyi dosvid. Tsentr innovatsii ta rozvytku, 165-170. (in Russian).

2. Dolgorukov, A. Case-study method as modern technology of vocational training. Available at: http://www.vshu.ru/ lections.php? Tab_id $=3 \& \mathrm{a}=$ info $\&$ id $=260$

3. Zhyhylei, Y. M. (2012). Formyrovanye professyonalnykh kompetentsyi s pomoshchiu keismetoda $\mathrm{v}$ vysshem obrazovanyy [Formation of professional competencies using the casemethod in higher education]. Prepodavatel KhKhI vek, 29-36. (in Russian).

4. Malysheva M.A. (2011). Sovremennye tekhnolohyy obuchenyia y ykh rol v obrazovatelnom protsesse [Modern technologies of teaching and their role in the educational process]. Sovremennnye tekhnolohyy obuchenyia v vuze (opyt NYU VShЭ v Sankt-Peterburhe). $-\mathrm{SPb}, 6-25$. (in Russian).

5. Basics of the case-method. Available at: http://www.pprog.ru/Osnovi\%20keismetoda.doc

6. Pohrebelnaia N. Y. (2008). Keis-metod kak uslovye formyrovanyia yssledovatelskykh sposobnostei studentov vuza [Case-method as a condition for the formation of research abilities of university students]. Nauka y shkola, 73. (in Russian).

7. Surmin Yu. P. (2005). Metod analizu sytuatsii (Case study) ta yoho navchalni mozhlyvosti. Hlobalizatsiia i Bolonskyi protses: problemy i tekhnolohii [Case-study method and 
its educational capabilities. Globalization and the Bologna process: problems and technologies], 71-82. (in Ukrainian).

8. Surmyn Yu.P.(2002). Sytuatsyonnyi analyz, yly Anatomyia Keis-metoda [Situational Analysis, or Case Method Anatomy]. Tsentr ynnovatsyi y razvytyia, 41-56. (in Russian).

\title{
РЕЗЮМЕ
}

\author{
Анатолий Деревянчук, \\ кандидат технических наук, профессор \\ Сумской государственный университет
}

\section{Подход к созданию и применению кейс-метода при изучении военно-технических дисциплин}

Освещчается сущность применения метода «Case-study», как интерактивной формы обучения студентов военно-техническим дисциплинам с иелью повымения уровня качества преподавания дисциплины «Устройство и эксплуатаџия артиллерийского вооружения».

Предоставляются этапы создания кейсов, их содержание и методика проведения занятий.

Ключевые слова: интерактивные методики; кейс-метод; технологии обучения.

\section{SUMMARY}

Anatoliy Derevjanchuk,

Candidate of technical sciences, professor

Sumy State University

\section{An approach to the creation and application of a case-method in the study of military- technical disciplines}

This article describes issues, how to use case-method in war academies and military arts division with study military and technical disciplines.

At the beginning, the author show military-political situation at the East of Ukraine, opportunities of weapons and professional skills of soldiers for exploitation it. At this article the author describes one of the main problem - quality of training military specialist with use a casestudy. One of the important, the author used references and own experience has shown relevance and perspective for using case-method with study military and technical disciplines.

The aim of this article is comprehension of development and using case-study at training system of military specialist. The author predicts decision of next issues: the comprehension and essence of cases structure; formulation of requirements for create a general procedure of casemethod; give recommendations for include case-method in training practice.

At this article using an analysis of cases, synthesis of references about training military specialists, and results of experimental research. The main of researching result is development of training model with case-method.

The scientific novelty of this article is: for the first time, have been proposed an approach for development and using case-method with study military and technical disciplines; the sequence of development and including case-method in training process. Should be allocated, when traditional and interactive methods of training combine, students (cadets) have opportunities for raise them level of theoretical knowledge and practical skills at sphere of analysis some situations. This forces them to think, search the information, allocate the main think and find the right solutions of issues by themselves. Considering this situation with using case-method, it is expedient to improve the structure of case-method and methodic of this process.

Key words: interactive techniques; case-method; teaching technologies. 